\title{
BRPKM
}

Buletin Riset Psikologi dan Kesehatan Mental

http://e-journal.unair.ac.id/index.php/BRPKM

e-ISSN: 2776-1851

ARTIKEL PENELITIAN

\section{Pengaruh Self-Esteem dan Self-Efficacy terhadap Kecenderungan Postpartum Depression pada Ibu Primipara}

\author{
CANDRA KUSUMAWATI \& ENDANG RETNO SURJANINGRUM* \\ Fakultas Psikologi Universitas Airlangga
}

\begin{abstract}
ABSTRAK
Penelitian ini bertujuan untuk mengetahui adakah pengaruh self-esteem dan self-efficacy terhadap kecenderungan Postpartum Depression pada ibu primipara di Kecamatan Ngrayun. Self-esteem merupakan penilaian diri yang tercermin dalam sikap positif atau negatif terhadap diri sendiri, sedangkan self-efficacy mengacu pada keyakinan terhadap kemampuan mereka dalam bertindak atau berperilaku. Penelitian ini merupakan penelitian kuantitatif yang melibatkan 60 ibu primipara dalam masa postpartum di Kecamatan Ngrayun. Alat ukur yang digunakan adalah Coopersmith Self Esteem Inventory for Adult (CSEI-A), Perceived Maternal Parental Self-Efficacy (PMP S-E) dan Edinburgh Postnatal Depression Scale (EPDS) versi Bahasa Indonesia. Analisis data menggunakan teknik statistik regresi dengan bantuan SPSS versi 22 for Windows. Berdasarkan hasil analisis diperoleh nilai $p$ untuk variabel self-esteem sebesar 0,007, sedangkan nilai $p$ variabel self-efficacy sebesar 0,172. Hal ini menunjukkan bahwa variabel yang secara signifikan berpengaruh terhadap variabel PPD adalah variabel self-esteem dengan besar pengaruh sebesar 11,9\%.
\end{abstract}

Kata kunci: ibu primipara, postpartum depression, self-esteem, self-efficacy

\begin{abstract}
The aim of this study is to determine the effect of self-esteem and self-efficacy on the tendency of Postpartum Depression to primiparous mothers in Ngrayun district. Self-esteem is a self-assessment that is reflected in positive or negative attitude towards oneself. Meanwhile, self-efficacy refers to the belief in their ability to act or behave. This research is a quantitative study involving 60 mothers in the postpartum period in Ngrayun District. The measuring instruments used Indonesian version of Coopersmith Self-Esteem Inventory for Adult (CSEI-A), Perceived Maternal Parental Self-Efficacy (PMP SE), and Edinburgh Postnatal Depression Scale (EPDS). Data analysis was performed using regression statistical technique with the help of SPSS version 22 for Windows. Based on the analysis, the p-value of variable self-esteem is 0,007 , while the p-value of the self-efficacy variable is 0,172 . This indicates that the variable that significantly influences the PPD variable is self-esteem with a large effect of $11,9 \%$.
\end{abstract}

Keywords: primiparous mothers, postpartum depression, self-esteem, self-efficacy

Buletin Penelitian Psikologi dan Kesehatan Mental (BRPKM), 2021, Vol. 1(2), 1161-1171

*Alamat korespondensi: Fakultas Psikologi Universitas Airlangga, Kampus B Universitas Airlangga Jalan Airlangga 4-6 Surabaya 60286. Surel: endang.surjaningrum@psikologi.unair.ac.id

Naskah ini merupakan naskah dengan akses terbuka dibawah ketentuan the Creative Common Attribution License (CC-BY-4.0) (http://creativecommons.org/licenses/by/4.0), 
sehingga penggunaan, distribusi, reproduksi dalam media apapun atas artikel ini tidak dibatasi, selama sumber aslinya disitir dengan baik.

\section{PEN D A H U L U A N}

Kehamilan serta kelahiran mengakibatkan perubahan multidimensional pada wanita. Masa tersebut juga merupakan periode yang krusial karena terjadi transisi sosial maupun psikologis sehingga dibutuhkan adaptasi dan penyesuaian diri selama periode tersebut (Bjelica dkk., 2018). Namun, tidak semua wanita atau ibu dalam kondisi psikologis yang baik sehingga mampu menyesuaikan dengan perubahan tersebut (Surjaningrum dkk., 2018). Khususnya pada ibu primipara, yaitu ibu yang melahirkan bayi hidup untuk pertama kali. Ibu primipara masuk dalam kriteria ibu yang rentan mengalami gangguan emosional dan membutuhkan dukungan tambahan pasca melahirkan (Bobak, Lowdermilk, \& Jensen, 1994). Penelitian menunjukkan bahwa primipara cenderung sangat peduli dengan perasaan dekat dengan bayi, perasaan cemas terhadap keadaan diri, dan keadaan bayinya (Afiyanti, Rachmawati, \& Nurhaeni, 2006). Hal tersebut dikarenakan pada primipara tidak hanya dihadapkan pada situasi yang sama sekali baru, tetapi juga memasuki periode yang sangat penting untuk integritas mereka sebagai proses perkembangannya menjadi ibu (Bjelica dkk., 2018).

Pengalaman memasuki masa awal transisi menjadi seorang ibu (motherhood period) tersebut mengakibatkan kesulitan serta ketidakmampuan ibu primipara untuk beradaptasi, sehingga ibu gagal menyesuaikan diri dan mengalami gangguan emosional atau psikologis, salah satunya Postpartum Depression (PPD). Dalam DSM-V Postpartum Depression disebut sebagai Major Depressive Disorder With Peripartum Onset, yaitu gangguan depresi mayor yang muncul pada periode kehamilan hingga melahirkan yang biasanya berlangsung selama 4 minggu setelah melahirkan (American Psychiatric Association, 2013). Meskipun depresi ini akan sembuh dalam beberapa minggu setelah kemunculan, namun ibu masih bisa mengalami relaps selama kehamilan berikutnya ataupun bahkan pada peristiwa yang tidak ada hubungannya dengan kehamilan (Stewart \& Vigod, 2016). Diperkirakan prevalensi PPD di negara Indonesia sendiri sebanyak 22,3\% (Nurbaeti dkk., 2018). Angka tersebut jauh lebih besar jika dibandingkan dengan prevalensi dari Postpartum Depression di dunia, yang diestimasikan sebesar 6,5\% sampai 12,9\% (Stewart \& Vigod, 2016).

Postpartum depression memiliki dampak negatif, baik jangka pendek maupun jangka panjang, baik pada diri ibu itu sendiri, juga pada anak dan keluarga (Nurbaeti dkk., 2018). Ibu yang mengalami depresi selama periode postpartum cenderung mengalami defisit kognitif dan gangguan tidur. Kondisi tersebut berdampak pada ketidakmampuan ibu dalam merawat anaknya secara memadai, sehingga muncul gangguan pada aspek biologis, sosial maupun keterlambatan perkembangan, serta psikologis anak (Smith-Nielsen dkk., 2016). Ibu yang mengalami depresi postpartum juga akan mengalami konflik pada keluarga dan pernikahan sehingga memungkinkan terjadi perceraian (Slomian dkk., 2019). Postpartum depression yang tidak segera ditangani juga dapat membahayakan nyawa ibu dan orang-orang sekitarnya. Sebuah literatur menyebutkan bahwa bunuh diri yang diakibatkan postpartum depression menyumbang sekitar $20 \%$ dari total kematian yang terjadi pada ibu yang sedang dalam masa postpartum (Lindahl, Pearson, \& Colpe, 2005). Sebuah artikel berita yang diterbitkan pada tanggal 21 April 2021 (Saputra, 2021), memuat bahwa pada awal tahun 2021 seorang ibu dari 2 anak di Bandung melakukan bunuh diri dikarenakan merasa gagal menjadi ibu. Kasus lain yang mengakibatkan kematian pada masa postpartum, yaitu pada tahun 2019 seorang ibu tega membunuh bayinya yang berumur beberapa bulan karena mengalami gangguan mental pada periode postpartum. Kasus serupa terjadi pada ibu asal Purwakarta, Jawa Barat, dimana ibu tersebut tega mengubur hidup-hidup bayinya yang 
berusia 5 bulan di belakang rumahnya. Tersangka disini mengalami depresi peripartum semenjak usia kehamilan 7 bulan (Ediyati, 2019). Kasus lain juga terjadi di Sukabumi, Jawa Barat, dimana seorang wanita berinisial A membacok suaminya sendiri karena mengalami depresi pasca melahirkan (Jayanti, 2019)

Terdapat berbagai faktor yang menjadi prediktor terjadinya postpartum depression pada ibu pasca melahirkan, diantaranya adalah faktor psikologis, yaitu kepribadian, khususnya self-esteem dan selfefficacy. Hal tersebut dikarenakan self-esteem dan self-efficacy berpengaruh terhadap terjadinya perubahan kognitif, yaitu persepsi atas diri sendiri pada ibu (Ramadhani, 2007). Dimana persepsi terhadap diri yang negatif akan berdampak pada kesejahteraan mental seseorang (Iancu, Bodner, \& Ben-zion, 2015). Selain itu, self-esteem dan self-efficacy mempengaruhi bagaimana orang tersebut bersikap serta bertindak dalam mencapai tujuannya (Ayunita \& Feriani, 2021).

Self-esteem adalah evaluasi atau penilaian yang dibuat oleh diri individu sendiri yang biasanya berhubungan dengan penghargaan terhadap dirinya sendiri (Coopersmith, 1967). Hasil dari penilaian ini mengekspresikan suatu sikap setuju atau tidak setuju dan menunjukkan tingkat keyakinan individu atas kemampuan, keberhasilan, perasaan penting dan berharga yang dimiliki dirinya. Peran self-esteem pada ibu pasca melahirkan erat kaitannya dengan sikap positif ataupun negatif yang ditunjukkan oleh ibu dalam mengasuh bayinya (Nurbaeti dkk., 2018). Ibu dengan self-esteem tinggi cenderung puas dengan karakter dan kemampuan yang dimiliki oleh dirinya. Adanya penerimaan dan penghargaan diri yang positif ini memberikan rasa aman dalam menyesuaikan diri atau beradaptasi serta bereaksi terhadap stimulus dari lingkungan sosial. Sementara itu, ibu pasca melahirkan dengan self-esteem rendah menunjukan level kecemasan yang lebih tinggi, dan lebih banyak menunjukan symtom psikosomatis dan perasaan depresi. Rosenberg (dalam Reasoner, 2010) menjelaskan bahwa individu dengan harga diri yang rendah seringkali mengalami depresi dan ketidakbahagiaan, memiliki tingkat kecemasan yang tinggi, menunjukan impuls-impuls agresivitas yang lebih besar, mudah marah dan pendendam, serta selalu menderita karena ketidakpuasan akan kehidupan sehari-hari. Dikarenakan hal tersebut, ibu primipara yang memiliki self-esteem rendah akan kesulitan melakukan melalui masa transisi peran serta melakukan tuntutan peran barunya sebagai ibu, sehingga lebih rentan mengalami postpartum depression. Pada penelitian terdahulu ditemukan bahwa self-esteem yang rendah berkorelasi dengan postpartum depression dimana hubungan yang dihasilkan adalah negatif, yaitu semakin tinggi self-esteem ibu, maka makin rendah Postpartum Depression yang dialami (Haryanti \& Puspitasari, 2021).

Self-efficacy adalah persepsi diri atas kemampuannya dalam merencanakan, mengorganisasikan, serta melaksanakan tindakan-tindakan yang mengarah pada tercapainya tujuan tertentu. Keyakinan atas kemampuan diri ini adalah dasar dari motivasi manusia, pencapaian kinerja, dan kesejahteraan emosional (Bandura, 1997). Self-efficacy pada ibu pasca melahirkan berkaitan dengan maternal selfefficacy. Maternal self-efficacy diartikan sebagai kompetensi yang dimiliki seorang dalam menjalankan peran sebagai orang tua secara khusus didefinisikan sebagai kepercayaan terhadap kemampuan dalam merawat bayi serta menjalankan peran sebagai ibu (Bandura, 1997). Sebuah penelitian menyatakan bahwa ibu yang memiliki maternal self-efficacy tinggi mempunyai kemampuan lebih baik dalam melakukan tugas sebagai orang tua, lebih tanggap dalam merespon setiap isyarat dan kebutuhan bayi (Porter \& Hui-Chin, 2003). Sedangkan ibu pasca melahirkan yang memiliki maternal self-efficacy yang rendah akan menjauhi atau menghindari melakukan tugas-tugas yang sulit karena tugas tersebut dipandang sebagai ancaman bagi mereka, termasuk saat menjalankan tugas untuk peran barunya sebagai ibu. Mereka juga akan terjebak dalam perenungan yang tidak produktif atau menyalahkan diri sendiri maupun orang lain (Szabo, 2015). Ibu primipara yang memiliki self-efficacy rendah akan kesulitan melakukan melalui masa transisi peran serta menjalankan tuntutan peran barunya sebagai 
ibu, sehingga lebih rentan mengalami postpartum depression. Berdasarkan pada penelitian sebelumnya ditemukan hasil analisis yang menunjukkan bahwa terdapat korelasi negatif yang kuat antara maternal self-efficacy dan postpartum depression (Fitria, Nurwati, \& Permatasari, 2020).

Kecamatan Ngrayun, merupakan salah satu kecamatan di Indonesia dengan kondisi masyarakat dan demografis yang menjadikan peluang terjadinya postpartum depression yang cukup tinggi. Topografi kecamatan Ngrayun terdiri dari daerah pegunungan dengan ketinggian di atas 553 mdpl yang memiliki kualitas sarana dan prasarana yang masih rendah yang mengakibatkan sulitnya menjangkau informasi, fasilitas pendidikan, serta fasilitas kesehatan (Rencana Program Investasi Jangka Menengah Bidang Cipta Karya Kabupaten Ponorogo Tahun 2017-202, 2016). Keadaan tersebut menjadikan masyarakat Kecamatan Ngrayun kurang aware akan masalah kesehatan mental serta penanganannya. Kesulitan sarana dan prasarana juga mengakibatkan masih tingginya kepercayaan atas adat istiadat ataupun budaya tentang pengasuhan bayi dan anak di Kecamatan Ngrayun. Menurut tenaga kesehatan setempat masih terdapat ketidaksesuaian antara arahan dari tenaga kesehatan dengan budaya dan kepercayaan yang dianut oleh masyarakat, contohnya seperti penggunaan bedong dan gurita pada bayi. Ketidaksesuaian arahan tersebut akan meningkatkan kemungkinan ibu primipara mengalami kebingungan, cemas, gelisah, serta merasa tidak mampu dalam menjalankan perannya sebagai ibu baru, sehingga meningkatkan resiko terjadinya gangguan mental pasca melahirkan (Kurniasari \& Astuti, 2015).

Selain itu, kondisi ekonomi dengan tingkat menengah ke bawah serta pendidikan yang rendah meningkatkan probabilitas pernikahan dini, dimana berdasarkan data BKKBN Kecamatan Ngrayun merupakan salah satu kecamatan yang ada di Ponorogo dengan angka pernikahan di bawah 20 tahun tertinggi pada tahun 2013, yaitu sejumlah 136 orang (Ernawati dkk., 2014). Padahal usia remaja yaitu di bawah 20 tahun dan diatas 35 tahun merupakan usia yang rawan dalam kehamilan. Usia sendiri terkait dengan kesiapan mental ibu dalam pengasuhan bayi yang akan berdampak pada tumbuh kembang anak (Santrock, 2011). Jadi, tingginya pernikahan dini di Kecamatan Ngrayun identik dengan tingginya kehamilan pada usia rawan, sehingga tinggi juga masalah kesehatan fisik maupun mental ibu yang mungkin muncul selama masa postpartum pada ibu primipara. Selain itu, tingkat ekonomi serta pendidikan yang rendah mengakibatkan rendahnya akses informasi yang dimiliki termasuk informasi mengenai kesehatan mental yang berdampak pada kurangnya pengetahuan serta penanganan yang benar apabila ibu primipara mengalami gangguan emosional pasca melahirkan (Ayunita \& Feriani, 2021).

Berdasarkan pemaparan diatas diketahui bahwa Kecamatan Ngrayun merupakan salah satu kecamatan di Indonesia dengan probabilitas terjadinya masalah kesehatan mental ibu pasca melahirkan yang cukup tinggi, namun masih sangat kurang informasi mengenai kesehatan mental. Oleh karena itu, penelitian tentang postpartum depression di Kecamatan Ngrayun penting untuk dilakukan. Kejadian postpartum depression berkaitan erat dengan perubahan kognitif dan psikologis selama transisi peran menjadi ibu pada primipara. Dimana perubahan tersebut dipengaruhi oleh karakter individu, khususnya penilaian terhadap diri serta kemampuan diri yang dipengaruhi oleh tingkat self-esteem dan self-efficacy yang dimiliki ibu. Dikarenakan hal tersebut penulis ingin meneliti lebih lanjut mengenai adanya atau tidaknya pengaruh antara self-esteem dan self-efficacy terhadap kecenderungan terjadinya postpartum depression pada ibu primipara di Kecamatan Ngrayun. 


\section{MET ODE}

\section{Desain Penelitian}

Penelitian ini termasuk penelitian kuantitatif-explanatory dikarenakan penelitian ini bertujuan untuk mengungkapkan hubungan kausal antara variabel-variabel dan pengujian hipotesis yang telah dirumuskan sebelumnya. Metodologi pengumpulan data yang akan digunakan dalam penelitian ini adalah survei dengan menggunakan kuesioner (Neuman, 2007).

\section{Partisipan}

Metode pengambilan sampel yang digunakan pada penelitian ini adalah purposive sampling yang termasuk dalam nonprobability sampling. Penggunaan teknik sampling tersebut dikarenakan peneliti tidak mengetahui jumlah populasi ibu primipara di Kecamatan Ngrayun serta pengambilan sampel didasarkan pada kriteria-kriteria yang telah ditentukan oleh peneliti (Neuman, 2014). Kriteria partisipan dalam penelitian ini adalah ibu primipara dengan masa persalinan minimal 1 bulan dan maksimal 12 bulan yang berdomisili di Kecamatan Ngrayun. Dalam DSM V disebutkan bahwa postpartum depression muncul pada periode kehamilan hingga melahirkan yang biasanya berlangsung selama 4 minggu setelah melahirkan (American Psychiatric Association, 2013). Sedangkan dalam praktik dan penelitian klinis, depresi postpartum secara bervariasi didefinisikan sebagai depresi yang terjadi dalam 4 minggu setelah melahirkan, atau 3 bulan, 6 bulan, hingga 12 bulan setelah melahirkan (Stewart \& Vigod, 2016). Adapun dalam penelitian ini penulis menentukan 1 bulan batas minimal dan 12 bulan sebagai batas maksimal. Selain itu, sampel penelitian ini terdiri dari ibu primipara yang bersedia menjadi partisipan penelitian dengan menandatangani informed consent yang disediakan.

Penelitian ini melibatkan 60 partisipan dengan rentang usia 16-29 tahun $\left(M_{\text {usia }}=22,15 ; S D_{\text {usia }}=2,827\right)$ dengan rentang pendidikan SD-S1 (SD=8,4\%; SMP=38,3\%; SMA/ SMK= 48,3\%; S1=5\%). Partisipan berasal dari 20 tempat posyandu yang ada di 3 desa, yaitu Desa Cepoko, Ngrayun, dan Temon, di Kecamatan Ngrayun. Pemilihan desa sebagai tempat pengambilan data tersebut didasarkan pada rekomendasi dari tenaga kesehatan di Puskesmas Kecamatan Ngrayun, yaitu desa-desa dengan probabilitas jumlah primipara tertinggi yang ada di Kecamatan Ngrayun. Besarnya sampel dalam penelitian ini ditentukan berdasarkan teori (Neuman, 2007), diketahui bahwa agar penelitian dapat memberikan hasil yang konsisten, jumlah sampel minimal dalam penelitian setidaknya berjumlah 30 . Selain itu, pendapat lain juga menyatakan bahwa pada penelitian regresi multivariat, ukuran sampel harus 10 kali lebih besar dari jumlah variabel yang dianalisis. Penelitian ini menggunakan 3 variabel yang akan dianalisis, maka jumlah sampel minimal adalah 30 (Roscoe, 1975).

\section{Pengukuran}

Terdapat tiga alat ukur yang digunakan untuk pengumpulan data. Dalam penelitian ini, variabel selfesteem diukur dengan menggunakan Coopersmith Self Esteem Inventory for Adult (CSEI-A) short form versi Bahasa Indonesia (Hariyadi \& Putri, 2012). CSEI-A merupakan adaptasi dari skala psikologis yang terdiri dari 25 aitem dengan 8 aitem favorable dan 17 item unfavorable dengan 2 pilihan jawaban $(0=$ "tidak"; $1=$ "ya") dengan reliabilitas yang cukup baik $(\alpha=0,81)$ (Coopersmith, 1967). Sedangkan untuk variabel self-efficacy yang dimiliki oleh ibu primipara diukur dengan kuesioner hasil adaptasi Perceived Maternal Parental Self-Efficacy (PMP S-E) yang dikembangkan oleh Barnes dan Adamson-Macedo berdasarkan dari teori Bandura. Alat ukur ini berbentuk skala likert yang terdiri dari 20 item dengan 4 jawaban (1="sangat tidak setuju"; 4="sangat setuju") dengan reliabilitas yang tinggi $(\alpha=0,91)$ (Mariana, 2016). Pada variabel Postpartum Depression pengambilan data menggunakan adaptasi dari alat ukur

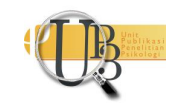


Edinburgh Postnatal Depression Scale (EPDS) yang berjumlah 10 pertanyaan mengenai perasaan dan suasana hati sang ibu dalam kurun waktu 7 hari (Cox, Holden, \& Sagovsky, 1987). Alat ukur ini berupa skala likert yang terdiri dari n 4 pilihan jawaban ( $0=$ "tidak pernah"; $3=$ "sering") dengan reliabilitas yang cukup baik $(\alpha=0,8)$ (Mariana, 2016).

\section{Analisis Data}

Pengujian hipotesis dalam penelitian ini dianalisis dengan teknik statistik korelasi serta regresi menggunakan bantuan software SPSS versi 22 for Windows. Sebelum itu dilakukan analisis deskriptif untuk mengetahui gambaran data, serta uji asumsi klasik sebagai persyaratan uji regresi. Terdapat 3 uji regresi yang dilakukan pada penelitian ini, yaitu secara simultan, parsial, dan terpisah.

\section{HAS IL P EN EL IT IAN}

Pengkategorian berdasarkan penormaan kelompok diperoleh skor self-esteem terbanyak pada kategori sedang, yakni sebanyak 44 partisipan dengan persentase 73,3\%. Pada urutan kedua, skor self-esteem terbanyak pada kategori rendah yakni sebanyak 9 partisipan dengan persentase $15 \%$. Selanjutnya, skor self-esteem berada pada kategori tinggi, yakni sebanyak 7 partisipan dengan persentase 11,7\%. Sama halnya dengan self-esteem, berdasarkan norma kelompok skor variabel self-efficacy juga dikategorikan menjadi 3, yaitu skor self-efficacy terbanyak pada kategori sedang yakni sebanyak 42 partisipan dengan persentase 70\%. Pada urutan kedua, skor self-efficacy terbanyak pada kategori tinggi yakni sebanyak 10 partisipan dengan persentase $16,7 \%$. Selanjutnya, skor self-efficacy berada pada kategori rendah yakni sebanyak 8 partisipan dengan persentase 13,3\%. Sedangkan pada pengkategorian skor variabel postpartum depression dilakukan dengan panduan skoring Edinburgh Postnatal Depression Scale (EPDS) (Cox et al., 1987), dengan hasil skor postpartum depression terbanyak pada kategori not depressed, yakni sebanyak 41 partisipan dengan persentase 68,3\%. Kemudian dilanjutkan skor postpartum depression berada pada kategori minor depression, yakni sebanyak 13 partisipan dengan persentase 21,7\%. Pada urutan terakhir, skor postpartum depression terbanyak pada kategori more major depression, yakni sebanyak 6 partisipan dengan persentase $10 \%$.

Berdasarkan hasil korelasi Pearson diketahui bahwa variabel self-esteem memiliki korelasi yang negatif dan sedang $(r(60)=-0,345 ; p=0,007<0,05)$ dengan variabel Postpartum Depression. Sedangkan hasil uji korelasi statistik nonparametrik Spearman's Rank Order diketahui bahwa variabel self-efficacy secara signifikan tidak berkorelasi $(r(60)=-0,220 ; p=0,091>0,05)$ dengan variabel postpartum depression. Selanjutnya, berdasarkan uji regresi secara simultan diketahui bahwa secara signifikan salah satu diantara variabel self-esteem dan self-efficacy berpengaruh terhadap variabel postpartum depression $\left(F(2,58)=3,15 ; p=0,009<0,05 ; R^{2}=0,152\right)$. Namun, berdasarkan uji regresi secara parsial (uji $t$ ) diketahui bahwa hanya variabel self-esteem berpengaruh secara signifikan terhadap variabel postpartum depression $(t(57)=-2,756 ; p=0,008<0,05)$, sedangkan pengaruh variabel self-efficacy terhadap variabel postpartum depression tidak signifikan $(t(57)=-1,490 ; p=0,142>0,05)$. Hasil serupa juga didapatkan dari uji regresi antara masing-masing variabel independen dengan variabel dependen secara terpisah. Berdasarkan uji regresi linear sederhana diperoleh hasil bahwa variabel self-esteem berpengaruh secara signifikan terhadap variabel postpartum depression $\left(F(1,2)=7,813 ; p=0,007<0,05 ; R^{2}=0.119\right)$. Berdasarkan hasil regresi nonparametrik Quadratic diketahui bahwa pengaruh variabel self-efficacy terhadap variabel postpartum depression tidak signifikan $\left(F(1,2)=1,792 ; p=0,176>0,05 ; R^{2}=0.059\right)$. 


\section{I S K U S I}

Penelitian ini bertujuan untuk melihat ada atau tidaknya pengaruh self-esteem dan self-efficacy terhadap kecenderungan postpartum depression pada ibu primipara di Kecamatan Ngrayun. Hasil analisis diperoleh bahwa hanya terdapat 1 variabel independen yang berpengaruh secara signifikan terhadap variabel dependen, yaitu variabel self-esteem. Namun, variabel self-efficacy secara signifikan tidak berpengaruh terhadap variabel postpartum depression. Besar pengaruh self-esteem terhadap kecenderungan terjadinya postpartum depression adalah sebesar $11,9 \%$, untuk 88,1\% lainnya dipengaruhi oleh faktor lain yang tidak diteliti.

Signifikansi pengaruh variabel self-esteem terhadap variabel postpartum depression tersebut sesuai dengan hasil penelitian terdahulu (Beck, 2001). Harga diri mengacu pada perasaan tentang nilai diri dan penerimaan diri seorang wanita secara umum. Harga diri ini mengenai kepercayaan dirinya dan kepuasan dalam dirinya. Harga diri yang rendah mencerminkan evaluasi diri dan perasaan tentang diri sendiri atau kemampuan seseorang yang negatif. Ibu dengan self-esteem rendah cenderung menilai diri mereka tidak mampu dan merasa pesimis, serta berkutat pada ketidakmampuan mereka daripada memikirkan solusi atas ketidakmampuan tersebut. Hasil uji regresi ini selaras dengan hasil uji korelasi. Berdasarkan hasil uji korelasi Pearson, diketahui bahwa terdapat korelasi yang signifikan antara variabel self-esteem dan variabel Postpartum Depression. Hal tersebut selaras dengan penelitian terdahulu bahwa self-esteem berkorelasi negatif dengan postpartum depression (Haryanti \& Puspitasari, 2021).

Berdasarkan hasil analisis regresi variabel self-efficacy pada penelitian ini diketahui bahwa tidak terdapat pengaruh yang signifikan antara variabel self-efficacy terhadap variabel postpartum depression. Self-efficacy adalah persepsi diri atas kemampuannya dalam merencanakan, mengorganisasikan, serta melaksanakan tindakan-tindakan yang mengarah pada tercapainya tujuan tertentu. Pada penelitian ini diperoleh skor minimum variabel maternal self-efficacy sebesar 53 dari 80. Oleh karena itu, diasumsikan bahwa maternal self-efficacy yang dimiliki oleh ibu primipara di Kecamatan Ngrayun tinggi. Jadi, ibu primipara di Kecamatan Ngrayun memiliki kompetensi yang baik dalam merawat bayi serta menjalankan peran sebagai ibu.

Pengaruh yang tidak signifikan antara variabel self-efficacy dan postpartum depression mungkin dipengaruhi oleh hasil uji korelasi. Uji korelasi antara kedua variabel ini dilakukan dengan uji Spearman dan diperoleh hasil bahwa korelasi antara variabel self-efficacy dengan variabel Postpartum Depression tidak signifikan. Hal ini sesuai dengan hasil penelitian terdahulu (Mariana, 2016), dimana korelasi antara variabel maternal self-efficacy dan postpartum depression didapatkan nilai signifikansi yang lebih besar dari 0,05 ( $p=0,309)$, maka tidak ada korelasi yang signifikan antara kedua variabel tersebut. Tidak adanya pengaruh yang signifikan antara variabel maternal self-efficacy dengan variabel postpartum depression pada ibu primipara didukung oleh pernyataan terdahulu yang menyebutkan bahwa selfefficacy belum tentu dapat memprediksi efek yang ditimbulkan pada kesehatan mental orang tua (Hastings \& Brown, 2002). Penelitian lain mengatakan bahwa maternal self-efficacy tidak memiliki hubungan langsung terhadap kondisi psikologis ibu (Mariana, 2016). Maka, dapat diartikan bahwa maternal self-efficacy merupakan variabel yang bertindak sebagai penghubung atara postpartum depression dengan variabel independen lainnya.

Variabel yang mungkin berpengaruh terhadap postpartum depression adalah dukungan sosial, karena hasil dari penelitian terdahulu menggambarkan dukungan sosial sebagai sumber self- efficacy seorang ibu dalam menghadapi keadaan stres (Singer dkk., 1996). Faktor lain yang menyebabkan terjadinya postpartum depression atau depresi pasca melahirkan adalah faktor biologis. Salah satu faktor resiko terkuat adalah riwayat masalah suasana hati dan kecemasan, khususnya depresi dan anxiety yang tidak 
diobati selama kehamilan (Stewart \& Vigod, 2016). Perubahan hormon pasca kelahiran, yaitu turunnya kadar estrogen dan progesteron secara dramatis pasca melahirkan juga turut berkontribusi pada terjadinya depresi pada wanita yang rentan (Santrock, 2011). Faktor biologis lain penyebab postpartum depression adalah faktor genetik dikarenakan anak-anak dengan ibu yang mengalami postpartum depression memiliki peluang 3-5 kali lebih besar mengalami depresi data dewasa (Stewart \& Vigod, 2016). Selain itu, terjadinya Postpartum Depression juga dipengaruhu faktor demografis lain yang dimiliki oleh ibu primipara di Kecamatan Ngrayun, seperti riwayat persalinan, tingkat sosial ekonomi dan pendidikan, usia perkawinan, serta budaya serta kepercayaan masyarakat Ngrayun.

Pada penelitian ini diperoleh kategori ibu primipara di Kecamatan Ngrayun dengan minor depression sebanyak $21,7 \%$ yang mengindikasikan adanya gejala distress yang menimbulkan rasa tidak nyaman. Selain itu, prevalensi postpartum depression yang tergolong more major depression sebanyak 10\%. Pada kategori ini dibutuhkan asesmen tambahan karena kemungkinan depresi sangat tinggi. Prevalensi kejadian postpartum depression pada penelitian ini juga sama dengan prevalensi Postpartum Depression secara global. Prevalensi dari postpartum depression secara global berkisar antara 10\% hingga $20 \%$. pendapat lain menyatakan prevalensi dari postpartum depression di dunia diestimasikan sebesar 6,5\% sampai 12,9\% (Stewart \& Vigod, 2016).

\section{S I M P U L A N}

Berdasarkan hasil analisis data dalam penelitian ini, dapat disimpulkan bahwa terdapat berpengaruh yang signifikan antara self-esteem terhadap kecenderungan terjadinya Postpartum Depression pada ibu primipara di Kecamatan Ngrayun. Namun, variabel self-efficacy tidak berpengaruh secara signifikan terhadap kecenderungan terjadinya postpartum depression pada ibu primipara di Kecamatan Ngrayun. Besar pengaruh self-esteem terhadap kecenderungan terjadinya postpartum depression adalah sebesar 11,9\%, dan untuk 88,1\% lainnya dipengaruhi oleh faktor lain yang tidak diteliti.

Adapun saran untuk posyandu diharapkan tenaga kesehatan yang bertugas di tempat posyandu memberikan pendidikan kesehatan mental terhadap ibu hamil agar siap menghadapi masa postpartum dan parenting anak, sehingga bisa mencegah terjadinya postpartum depression pada ibu serta lebih siap untuk pengasuhan anak. Selain itu, diharapkan tenaga kesehatan memberikan pelatihan singkat mengenai psychological first aid kepada kader-kader di tempat posyandu. Hal tersebut dilakukan agar kader lebih aware serta tanggap terhadap kondisi kesehatan mental ibu primipara di tempat posyandu, serta mampu memberikan dukungan pada ibu primipara di tempat posyandu yang mengalami gejala gangguan mental pasca melahirkan. Selain itu, keluarga dan kerabat dekat dari ibu primipara juga diharapkan dapat lebih aware mengenai kondisi kesehatan mental ibu serta mampu memberikan dukungan yang positif bagi ibu primipara yang sedang menjalani transisi peran pada periode postpartum.

Ibu primipara diharapkan dapat meningkatkan self-esteem yang dimiliki dengan cara lebih mencintai diri sendiri dengan meluangkan waktu untuk me-time, seperti meditasi, serta melakukan self-care, mengurangi ekspektasi berlebihan terhadap diri sendiri maupun pada bayi, fokus pada apa yang sedang dikerjakan, tidak berlarut-larut dalam kesedihan karena melakukan kesalahan maupun karena menerima komentar negatif dari orang lain selama menjalankan peran sebagai ibu, menyadari bahwa diri tidak sempurna sehingga melakukan kesalahan adalah hal yang wajar, serta berbagai cara lainnya. Meningkatnya self-esteem yang dimiliki oleh ibu diharapkan dapat menjadikan perspektif terhadap diri sendiri yang lebih positif. Selain itu, diharapkan ibu primipara tidak enggan mencari dukungan dan bantuan dari orang lain untuk mencegah serta meringankan terjadinya postpartum depression. 


\section{U C A P A N T ER I MAKASIH}

Terimakasih kepada Allah SWT, keluarga, tenaga kesehatan di Kecamatan Ngrayun, dan seluruh pihak yang terlibat serta membantu proses penelitian ini.

\section{DEKLARASI POTENSI TERJADINYA KONFLIK KEPENTINGAN}

Candra Kusumawati dan Endang Retno Surjaningrum tidak bekerja, menjadi konsultan, memiliki saham, atau menerima dana dari perusahaan atau organisasi manapun yang mungkin akan mengambil untung dari diterbitkannya naskah ini.

\section{PUSTAKA ACUAN}

Afiyanti, Y., Rachmawati, I. N., \& Nurhaeni, N. (2006). PERBEDAAN KEPEDULIAN MATERNAL ANTARA IBU PRIMIPARA DAN IBU MULTIPARA PADA AWAL PERIODE POST PARTUM *, 10(2), 54-60.

American Psychiatric Association. (2013). DSM-5 (5th ed.). Washington, DC London, England.

Ayunita, T., \& Feriani, P. (2021). Hubungan Harga Diri dengan Tingkat Depresi Ibu Postpartum di Puskesmas Trauma Center Samarinda, 2(2), 895-902.

Bandura, A. (1997). Self-Efficacy: The Exercise of Control. New York: W.H. Freeman and Company.

Beck, C. T. (2001). Predictors of postpartum depression. Nursing Research, 50(5), 275-285. https://doi.org/10.1097/00006199-200109000-00004.

Bjelica, A., Cetkovic, N., Trninic-pjevic, A., \& Mladenovic-segedi, L. (2018). The phenomenon of pregnancy - a psychological view, 89(2), 102-106. https://doi.org/10.5603/GP.a2018.0017

Bobak, I. M., Lowdermilk, D. L., \& Jensen, M. D. (1994). Maternity Nursing. Missouri: The C.V. Mosby Company.

Coopersmith, S. (1967). The antecedents of self-esteem San Francisco. H Freeman and Company.

Cox, J., Holden, J., \& Sagovsky, R. (1987). Detection of postnatal depression: Development of the 10-item Edinburgh Postnatal Depression Scale. British Journal of Psychiatry, 150, 782-786.

Ediyati, A. (2019). Memahami Depresi Postpartum Ibu yang Kubur Bayinya Hidup-hidup. Retrieved from https://www.haibunda.com/kehamilan/20190329185440-49-37192/memahami-depresipostpartum-ibu-yang-kubur-bayinya-hidup-hidup

Ernawati, H., Verawati, M., Kesehatan, F. I., \& Ponorogo, U. M. (2014). Kesehatan ibu dan bayi pada pernikahan dini, 3(3).

Fitria, I., Nurwati, R., \& Permatasari, D. P. (2020). Peran maternal self-efficacy sebagai mediator antara perceived social support dan depresi peripartum, 9(1), 170-189. 
Hariyadi, S., \& Putri, R. A. (2012). Harga diri pensiunan pegawai negeri sipil di kabupaten kendal. INTUISI, Jurnal Psikologi Ilmiah, 4(2), 2-5.

Haryanti, P., \& Puspitasari, R. (2021). Faktor-Faktor yang Berhubungan dengan Depresi pada Ibu Postpartum di Kota Yogyakarta, 12(April), 53-57.

Hastings, R. P., \& Brown, T. (2002). Behavior Problems of Child With Autism, Parental Self-Efficacy, and Mental Health. American Journal of Mental Retardation, 3(107), 222-232.

Iancu, I., Bodner, E., \& Ben-zion, I. Z. (2015). ScienceDirect Self esteem , dependency, self-efficacy and self-criticism in social anxiety disorder. Comprehensive Psychiatry, 58, 165-171. https://doi.org/10.1016/j.comppsych.2014.11.018

Jayanti, N. U. (2019). Istri Bacok Suami Karena Baby Blues? Ini Komentar Psikolog. Retrieved from https://health.detik.com/berita-detikhealth/d-4626374/istri-bacok-suami-karena-baby-bluesini-komentar-psikolog?

Kurniasari, D., \& Astuti, Y. A. (2015). Hubungan antara karakteristik ibu, kondisi bayi dan dukungan sosial suami dengan postpartum blues pada ibu dengan perslainan SC di Rumah Sakit Umum Ahmad Yani Metro tahun 2014. Jurnal Kesehatan Holistik, 3, 115-125.

Lindahl, V., Pearson, J. L., \& Colpe, L. (2005). Prevalence of suicidality during pregnancy and the postpartum. Archives of Women's Mental Health, 8(2), 77-87. https://doi.org/10.1007/s00737005-0080-1

Mariana, N. (2016). Hubungan Antara Maternal Self-Efficacy dengan Depresi Postpartum pada Ibu Primipara. Universitas Airlangga.

Neuman, W. L. (2007). Basic of Social Research: Qualitative and Quantitative Approach (2-nd ed.). Pearson Education, Inc.

Neuman, W. L. (2014). Social Research Methods: Qualitative and Quantitative Approaches (7th ed.).

Nurbaeti, I., Deoisres, W., \& Hengudomsub, P. (2018). Postpartum Depression in Indonesian Mothers : Its Changes and Predicting Factors. Pacific Rim Int J Nurs, (2), 93-105.

Ramadhani, A. (2007). Strategi Penanggulangan (Coping) pada Ibu yang Mengalami Postpartum Blues di Rumah Sakit Umum Daerah Kota Semarang: Sebuah Penelitian Kualitatif dengan Pendekatan Fanemologi. Universitas Diponegoro.

Reasoner, R. W. (2010). Extending Self esteem Theory And Research. Retrieved from http://www.selfesteem-internasional.org/content/5aresearch.htm

Pemerintah Kabupaten Ponorogo. (2016). Rencana Program Investasi Jangka Menengah Bidang Cipta Karya Kabupaten Ponorogo Tahun 2017-202. Ponorogo.

Roscoe, J. T. (1975). Fundamental Research Statistics for the Behavioural Sciences (2nd ed.). New York: Holt Rinehart \& Winston. 
Santrock, J. W. (2011). life-span Development (13th ed.). Erlangga.

Saputra, Y. (2021). Kesehatan mental: Depresi perinatal, pembunuh senyap yang mengintai keselamatan jiwa ibu dan anaknya. Retrieved from https://www.bbc.com/indonesia/indonesia56714093

Singer, L. T., Davillier, M., Bruening, P., Hawkins, S., \& Yamashita, T. S. (1996). Social Support, Psychological Distress, and Parenting Strains in Mothers of Very Low Birthweight Infants. Family Relations, 45(3), 343-350.

Slomian, J., Honvo, G., Emonts, P., Reginster, J., \& Bruyere, O. (2019). Consequences of Infant, maternal postpartum depression: A systematic review of maternal and outcomes. Woman Health.

Smith-Nielsen, J., Tharner, A., Krogh, M. T., \& Vaever, M. S. (2016). Effects of maternal postpartum On, depression in a well-resourced sample: Early concurrent and long-term effects infant cognitive, language, and motor development. Scand J Psychol, 57, 571-83.

Stewart, D. E., \& Vigod, S. (2016). Postpartum Depression. The New Engl and Journal of Medicine Clinical, 2177-2186. https://doi.org/10.1056/NEJMcp1607649

Surjaningrum, E. R., Jorm, A. F., Minas, H., \& Kakuma, R. (2018). Personal attributes and competencies required by community health workers for a role in integrated mental health care for perinatal depression : voices of primary health care stakeholders from Surabaya, Indonesia.

Szabo, M. (2015). Maternal Self-Efficacy and Role Satisfaction: The Mediating Effect of Cognitive Emotion Regulation. https://doi.org/10.1007/s10826-015-0217-4 